\title{
A Study of Cytological Variation in Chromosomal Races of Two Species of Cenchrus
}

\author{
D. R. Jagannath and V.S. Raman \\ Agricultural College and Research Institute, Coimbatore, India
}

Received April 25, 1972

C. ciliaris $\mathbf{L}$. and $C$. setigerus Vahl., the promising fodder grasses are reported to occur in warmer regions of both the hemispheres. The two species co-exist in pastures, are polymorphic and show intraspecific variation in chromosome numbers. In C. setigerus, only two chromosomal forms viz., $2 n=36$ and 54 have so far been isolated, whereas in $C$. ciliaris as many as ten viz., $2 \mathrm{n}=32,34,36,38$, 40, 42, 44, 52, 54 and 56 have been identified (Donald 1953, Darlington and Wylie 1955, Jogindernath and Swaminathan 1957, Patil et al. 1961, Chandrasekharan 1961, Jagannath 1963, Ponnaiya et al. 1966). The irregularities in chromosomal behaviour at meiosis and the variation in chromosome number resulting therefrom in the progenies are maintained in the population due to aposporous and facultative apomixis (Fisher et al. 1954, Synder et al. 1955). Concurrent with this, high morphological variation is also noticed in both the species, though the range of variation in the two is different. Chromosome behaviour at meiosis in four chromosomal forms has been traced and described below together with a consideration on the cytogenetic basis of variation in the complex.

\section{Material and methods}

Four chromosomal forms $(2 \mathrm{n}=36,44,54$ and 56) in $C$. ciliaris and two in $C$. setigerus $(2 \mathrm{n}=36$ and 54$)$ were studied. Young panicles were fixed in Carnoy's fluid (3:4:1) and stored in 70 percent alcohol. Meiosis was studied in temporary acetocarmine smears of pollen mother cells.

\section{Observations}

In C. setigerus $(2 \mathrm{n}=36)$, a maximum association of $4_{\mathrm{IV}}+10_{\mathrm{Ir}}$ was observed. In no case complete bivalent formation occurred. At anaphase $\mathrm{I}$, twenty of the eighty-two cells analysed gave 18/18 separation. In about forty-two percent of the cells, no laggards or bridges were met with; in the rest, 1-7 laggards comprising bivalents and univalents occurred. Normal as well as scattered plates at metaphase II, tetrads with spores of varying sizes, supernumerary spores and sporads with micronuclei were met with (Figs. 1-5). The fertile grains or at any rate the grains possessing normal visual viability were of different sizes. The maximum association observed in the $54(2 \mathrm{n})$ chromosome forms of this species was $1_{\mathrm{VI}}+$ $66_{\mathrm{IV}}+11_{\mathrm{II}}+2_{\mathrm{I}}$. The hexavalent was either frying-pan or chain shaped. A clear 

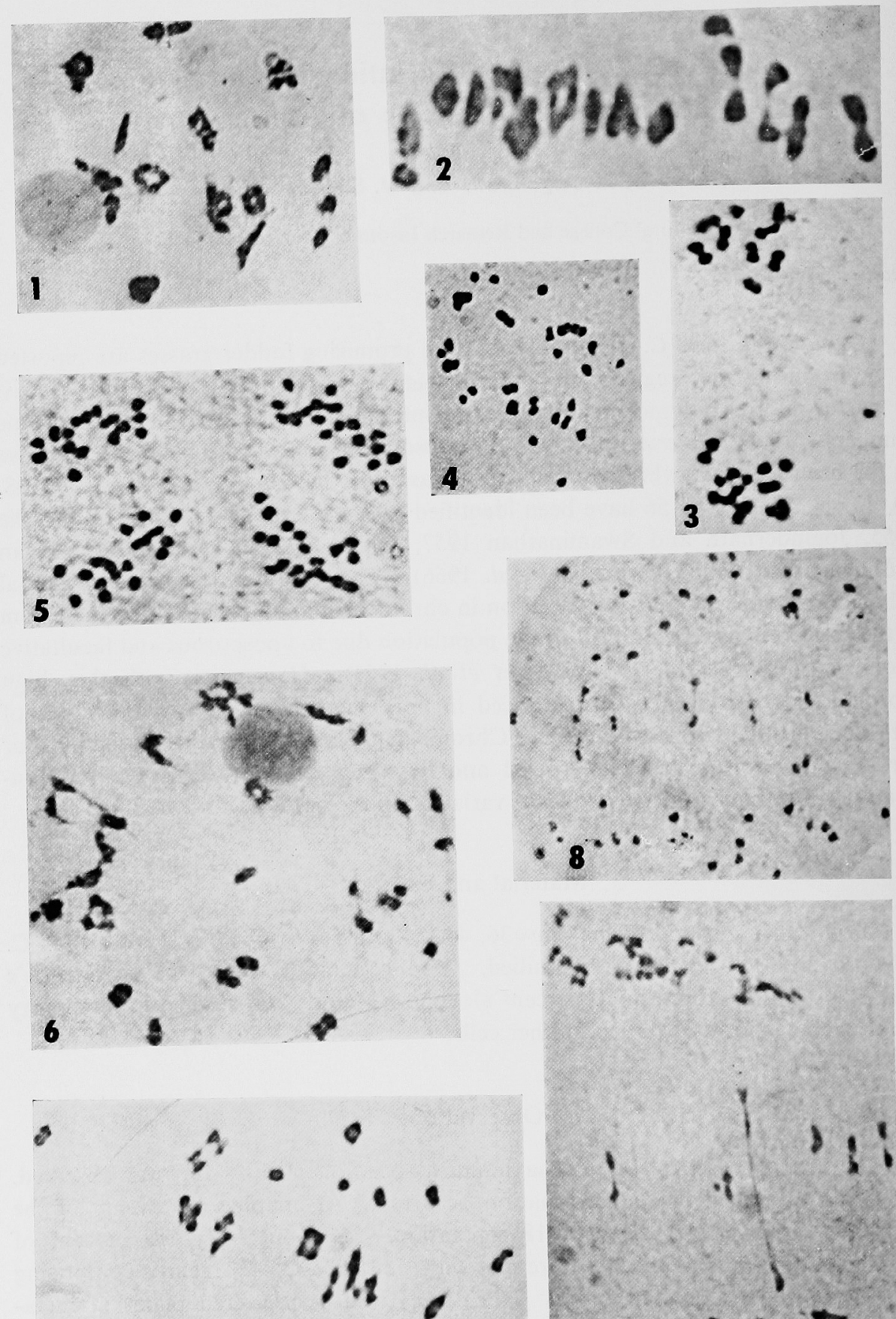

7

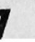

Figs. 1-5. C. setigerus $(2 n=36)$. Figs. 3 and $9 \times 1600$; rest $\times 1200$. 1 , diakinesis $\left(4_{I V}+88_{I I}+4 I\right)$ 2 , MI $\left(3_{I V}+11_{I I}+2_{I}\right)$. 3, M II with a laggard. 4, AI showing $2_{I V}+5_{I I}+18_{I}$. 5, T II $(17 / 18$ and $18 / 19$ distribution). Figs. 6-9. C. ciliaris $(2 \mathrm{n}=44)$. 6, diakinesis $\left(2_{\mathrm{IV}}+14_{\mathrm{II}}+8_{\mathrm{I}}\right) .7$, MI $\left(3_{I V}+15_{I I}+2 \mathrm{I}\right) .8$, and 9 , AI showing division of univalents. 

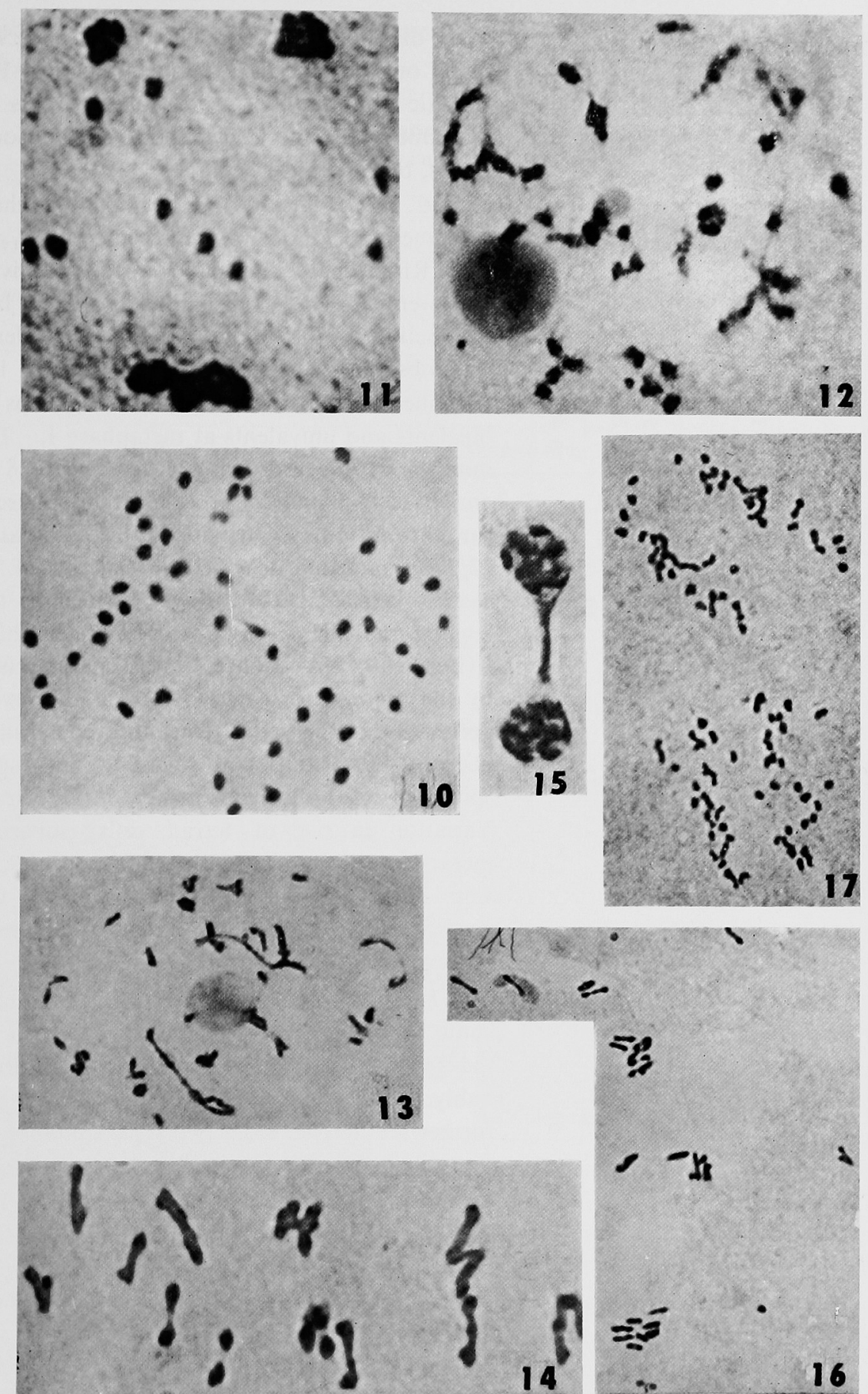

Figs. $10-12 . \quad C$. setigerus $(2 n=54)$. Figs. 11,12 and $14 \times 1500$ : rest $\times 1000,10$, AI with $20 / 24$ distribution. 11, TI with 9 chromosomes lagging. 12, diakinesis showing $1_{\mathrm{VI}}+2_{\mathrm{IV}}+2_{\mathrm{III}}+14_{\mathrm{II}}$ $+6 \mathrm{I}$. Figs. 13-17. C. ciliaris $(2 \mathrm{n}=56)$. 13, diakinesis $\left(1_{\mathrm{VI}}+2_{\mathrm{IV}}+1_{\mathrm{III}}+17_{\mathrm{II}}+5_{\mathrm{I}}\right) .14$, MI showing $2 \mathrm{VI}_{\mathrm{I}}+10_{\mathrm{IV}}+2_{\mathrm{II}}$. 15 , interkinesis with a persisting bridge. 16, AII showing scattered groups. 17, AII showing almost an equal distribution of chromosomes. 


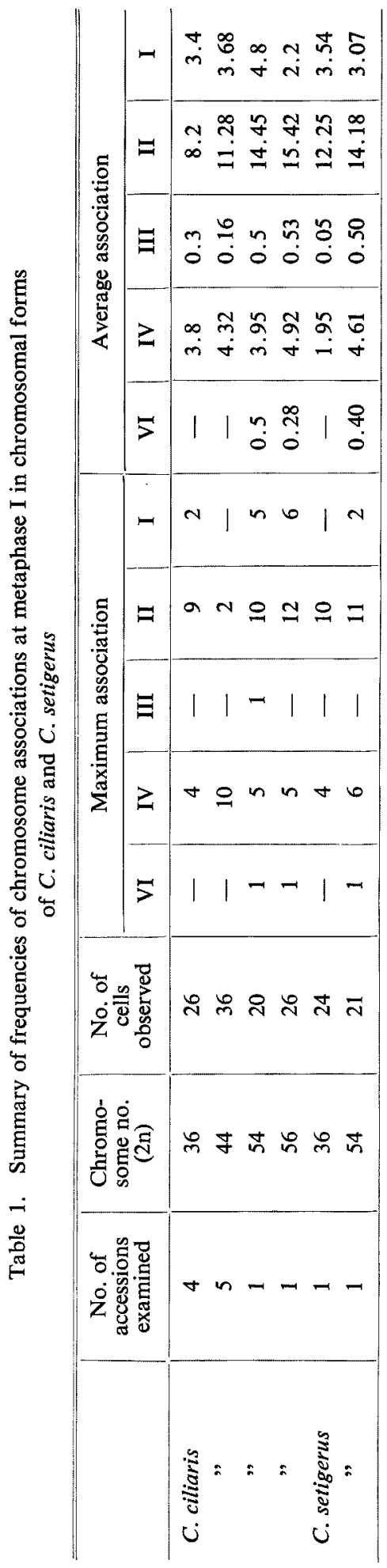

27/27 distribution at anaphase I was observed in 12 out of 44 cells examined (Figs. 10-12). Meiotic abnormalities were more or less of the same kind as noticed in the 36-chromosome forms, but differed in degree.

C. ciliaris $(2 \mathrm{n}=44)$ : The maximum chromosome association was represented by $10_{\mathrm{IV}}+$ $2_{\text {II }}$. Ring, chain and pan-shaped quadrivalents were present. Precocious as well as late disjunction of the multivalents and bivalents was observed. Eighty-six cells out of 140 examined showed 1 to 5 scattered groups of bivalents and univalents at metaphase $I$. The number of laggards ranged from 1 to 8 at anaphase I. Analysis of cells at telophase I for chromosome distribution showed that a $22 / 22$ separation occurred in 26 out of 58 cases. Persistence of bridges formed by the lagging univalents was observed at telophase I (Figs. 6-9). Anaphase II was characterised by the presence of laggards which, however, persisted in the cytoplasm and constituted micronuclei. Multipolar spindles and split spindles were observed rather infrequently. Variation in size of tetrad cells, supernumerary spores and spores with micronuclei were met with (Tables 1-5). In one of the accessions, twin seedlings were recorded in 7 percent of the seeds sown.

The course of meiosis in the 56-chromosome form in general, was similar to that of the 54-chromosome type (Figs. 13-17). Probably, the additional chromosomes in the former are derived from two separate pairs.

Pollen sterility varied in the different clones of the chromosomal forms of the species. In the two $(2 n=35$ and 44$)$ of $C$. ciliaris, the range was from 26 to 42 percent while in the hexaploid it varied from 46 to 52. In C. setigerus $(2 n=36)$ the sterility was 34 percent; a significant reduction in the sterility of pollen was observed in the hexaploid compared to its counterpart in $C$. ciliaris. Estimates of the aberrations noticed at anaphase I and in the sporads are given 
in Tables 3 and 5. Potted plants of the chromosomal races of the two species are illustrated in Fig. 18.

Table 2. Frequency of scattered groups of chromosomes (bivalents and univalents) at metaphase I

\begin{tabular}{l|c|c|c|c|c|c|c|c}
\hline \hline & $\begin{array}{c}\text { Chromo- } \\
\text { some } \\
\text { no. (2n) }\end{array}$ & $\begin{array}{c}\text { No. of } \\
\text { cells } \\
\text { examined }\end{array}$ & \multicolumn{4}{|c|}{ Number of groups } & \multirow{2}{*}{$\begin{array}{c}\text { No of } \\
\text { cells with } \\
\text { groups }\end{array}$} \\
\cline { 5 - 9 } & 36 & 140 & 10 & 16 & 40 & 11 & - & 77 \\
\hline C. ciliaris & 44 & 140 & 7 & 29 & 33 & 13 & 4 & 86 \\
\hline
\end{tabular}

Table 3. Frequency of bridges at anapahse I

\begin{tabular}{|c|c|c|c|c|c|c|c|}
\hline & \multirow{2}{*}{$\begin{array}{l}\text { Chromo- } \\
\text { some no. } \\
\text { (2n) }\end{array}$} & \multicolumn{6}{|c|}{ Number of bridges } \\
\hline & & 1 & 2 & 3 & 4 & 5 & 6 \\
\hline C. ciliaris & 36 & 16 & 33 & 14 & 18 & 一 & - \\
\hline$"$ & 44 & 32 & 16 & 4 & 3 & 3 & - \\
\hline$"$ & 54 & 23 & 12 & 6 & 2 & 5 & - \\
\hline$"$ & 56 & 16 & 12 & 4 & 2 & 5 & 1 \\
\hline C. setigerus & 36 & 13 & 10 & 9 & 3 & 5 & - \\
\hline " & 54 & 23 & 6 & 8 & 3 & 10 & - \\
\hline
\end{tabular}

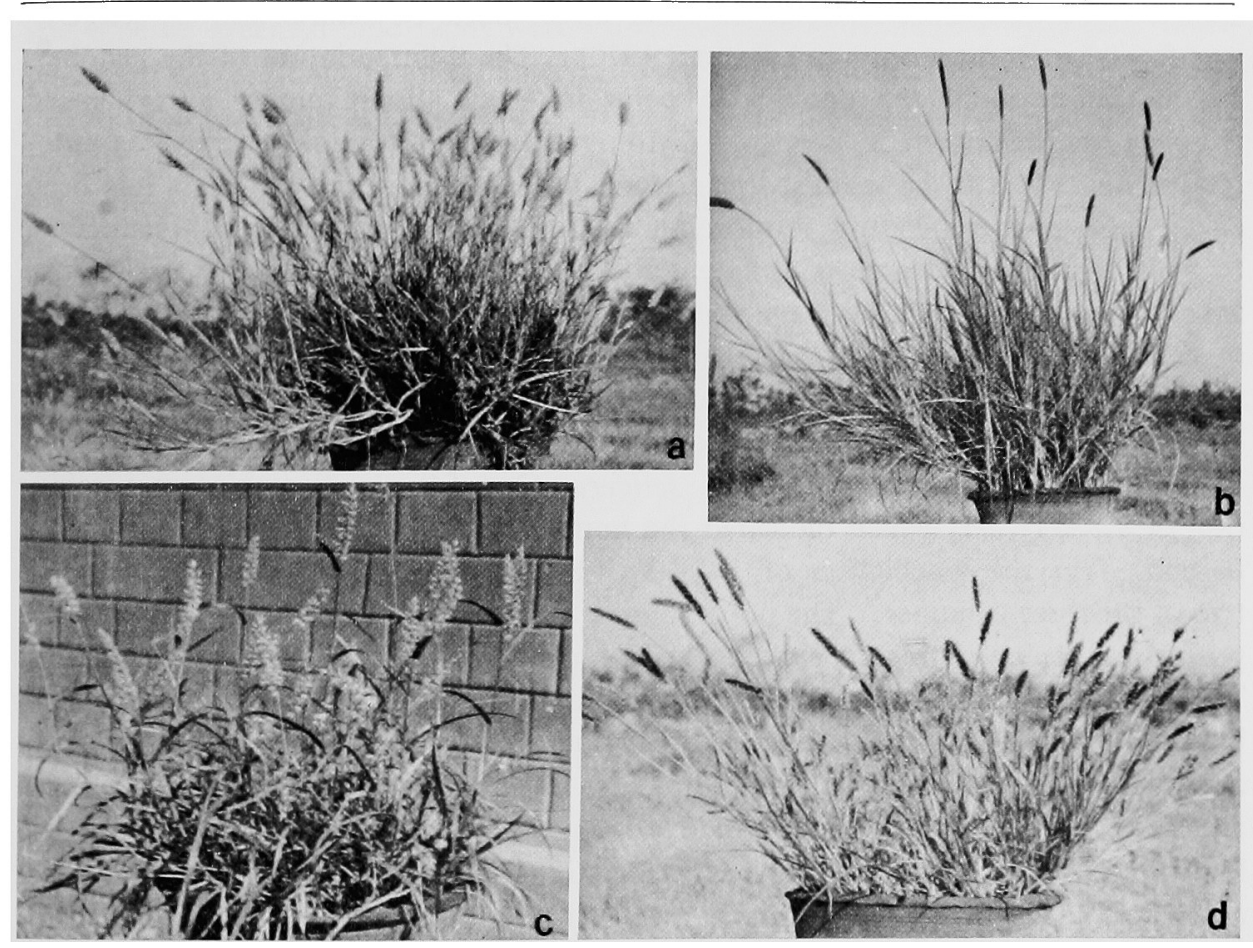

Fig. 18. a-c. Potted plants of C. ciliaris. a, $2 n=36 . \quad$ b, $2 n=44 . \quad c, 2 n=54 . \quad$ d, C. setigerus, $2 n: 36.1 / 10$ nat. size. 
Table 4. Distribution of chromosomes at telophase I

\begin{tabular}{l|cccc|cccccc|cccc}
\hline & \multicolumn{3}{|c|}{$2 \mathrm{n}=36$} & \multicolumn{5}{|c|}{$2 \mathrm{n}=44$} & \multicolumn{4}{|c}{$2 \mathrm{n}=54$} \\
\cline { 2 - 14 } & $\frac{18}{18}$ & $\frac{17}{19}$ & $\frac{16}{20}$ & $\frac{21}{15}$ & $\frac{18}{26}$ & $\frac{19}{25}$ & $\frac{20}{24}$ & $\frac{21}{23}$ & $\frac{22}{22}$ & $\frac{27}{27}$ & $\frac{28}{26}$ & $\frac{29}{25}$ & $\frac{30}{24}$ \\
\hline C. ciliaris & 30 & 36 & 18 & 12 & 4 & 6 & 10 & 12 & 26 & 16 & 12 & 6 & 2 \\
C. setigerus & 20 & 26 & 23 & 13 & - & - & - & - & - & 12 & 17 & 9 & 6 \\
\hline
\end{tabular}

Table 5. Frequencies of quartets with micronuclei and supernumerary spores

\begin{tabular}{|c|c|c|c|c|c|c|c|c|c|c|c|c|}
\hline & \multirow{2}{*}{$\begin{array}{l}\text { Chromo- } \\
\text { some } \\
\text { number } \\
(2 n)\end{array}$} & \multicolumn{6}{|c|}{$\begin{array}{l}\text { Number of micronuclei } \\
\text { in tetrad }\end{array}$} & \multicolumn{5}{|c|}{ Supernumerary spores } \\
\hline & & 1 & 2 & 3 & 4 & 5 & 6 & Diad & Triad & Tetrad & Pentad & Hexad \\
\hline C. ciliaris & 36 & 10 & 17 & 16 & 19 & 23 & 18 & - & - & - & - & - \\
\hline$"$ & 44 & 一 & - & - & - & - & - & 12 & 6 & 44 & 25 & 1 \\
\hline$"$ & 54 & 15 & 21 & 10 & 19 & 26 & - & - & - & - & - & - \\
\hline C. setigerus & 54 & - & - & - & - & - & - & 10 & 6 & 12 & 21 & 18 \\
\hline
\end{tabular}

\section{Discussion}

The quadrivalent frequencies varied in different accessions with 36 (2n) chromosomes. The maximum association observed in both $C$. ciliaris and $C$. setigerus was $8_{\text {IV }}+2_{\text {II }}$ (Ramaswamy and Raman 1970). The differentiation of the genomes has not been significant enough to point to strict allopolyploidy as evidenced from pairing behaviour at meiosis. Cytologically, the tetraploids behave as autotetraploids. It is to be surmised, therefore, that tetraploidy in the main has been effective in conserving and reinforcing the original combination of characters. In view of the low degree of differentiation between the genomes of the diploid ancestors, the hybrid should have been reasonably fertile and with the development of factors which will allow the fertilisation of diploid gametes should have contributed to the variability in the tetraploids. The associations observed in the higher chromosomal forms indicate different degrees of duplication.

The polyhaploids detected in $C$. setigerus $(2 n=54)$ gave a maximum association of $8_{I I I}+1_{I I}+1_{I}$ which indicated the homology of the three genomes involved therein. Yet the association of $1_{\text {III }}+8_{\text {II }}+8_{\text {I }}$ suggested the closer homology of two of the three genomes. The polyhaploids had reduced size of plant parts besides possessing denser setting of spikelets and longer bristles,-features of $C$. ciliaris. The morphological characteristics of the polyhaploid as well as its cytological behaviour at meiosis pointed to introgression from the allied taxon. It is conceivable that in the origin of the tetraploids, three partially differentiated genomes are involved. Thus, different combinations of the genomes at the tetraploid level could bring about the varying associations of chromosomes noticed in the accessions. The combination of characteristics in the higher chromosomal forms is probably brought about by hybridisation followed by aberrations in meiosis contributing to polyploidy. Their stability is strengthened by the occurrence of 
a gamospermy and vegetative apomixis. The chromosome associations observed in the hexaploid confirm the segmental homology of the duplicated genomes.

The two species being sympatric and cross-pollinated, the formation of hexaploid hybrid forms through $2 \mathrm{n} \times \mathrm{n}$ gametic fusion can be prevalent in nature. The seedling progenies of the haploid in C. setigerus consisted of 27 and 45 chromosome forms. A hexaploid hybrid of $C$. ciliaris, quite distinct from the natural forms of the species was also obtained by crossing two tetraploids $(2 n=36)$ of Indian and African origin (Ramaswamy and Raman 1969). It is evident that functioning of unreduced egg is a common feature which contributed to the apomictic phenomenon in these species.

It is pertinent to examine the morphological variation in relation to chromosomal forms in natural populations of the two species. The tetraploids of $C$. ciliaris exhibited wider variability than the clones with 44 (2n) chromosomes. In many of the tetraploids, the rhizomes were found to be not vigorous, whereas the $2 n=44$ forms exhibited high vigour, irrespective of their origin. The density of spikelets varied considerably among the different clones without any association to their chromosome numbers $(2 \mathrm{n}=34,36,44,54$ and 56). No consistent relationship could also be established between length/breadth value of leaf and length/thickness values of internode and peduncle on one hand and the chromosomal forms on the other. The colour of foliage viz., green, bluish-green or greenish-blue appeared to be a varying characteristic among the clones of $C$. ciliaris but not of $C$. setigerus. The blue or greenish-blue types were more strongly rhizomatous with little hairiness, high spikelet density and thicker peduncles. The clones with 44-chromosomes also showed variation in the colour of foliage but the association of other characters appeared to be not constant in contrast to the tetraploid forms. The tetraploids are determined distinctly from their 54-chromosome counterparts without intermediary in the expression of characters. The $2 \mathrm{n}=56$ form resembled the hexaploid in external morphology. In C. setigerus, the 36 and 54 chromosome forms stand distinctly separated from each other, the latter showing more vigour, taller growth, higher tillering capacity, denser setting of spikelets and greater thickness and length of peduncle. The foliage colour is green in both the forms. The pattern of morphological variation in the chromosomal groups does not indicate any strong association of chromosomal status with a specific combination of characters (Ramaswamy et al. 1969).

The meiotic aberrations encountered were essentially of the same kind, but their frequencies were dissimilar in different accessions. The variation in pollen sterility is attributable to genic causes which operate to bring about the degeneration of microspores. Chromosomal irregularities also contribute to the sterility met with. The cytological abnormalities could also be due to genic and physiological factors. Seed production, however, is copious. The morphological sharacteristics of the different chromosomal races of the two species, the irregularities in chromosomal behaviour at meiosis and the variation in chromosome number resulting therefrom in natural and experimental populations being maintained due to aposporous and facultative apomixis suggest that the cyto-types conititute an agamic complex. 


\section{Summary}

Variation in meiotic behaviour was analysed in accessions belonging to four chromosomal races $(2 \mathrm{n}=36,44,54$ and 56) in two species of Cenchrus.

All the accessions possessed the same chromosomal irregularities during the process of meiosis. The aberrations encountered were essentially of the same kind, but their frequencies were dissimilar in different accessions. These irregularities were the presence of univalents and multivalents, lagging chromosomes and chromosome bridges at anaphase I, laggards at anaphase II and numerous micronuclei at both the dyad and tetrad spore stages. These are commonly associated with polyploidy and hybridisation and both the factors are involved in the evolution of the complex.

Evidence from chromosome associations points to the allopolyploid nature of the chromosomal forms and the segmental homology of the duplicated genomes.

\section{References}

Chandrasekharan, P. 1961. Cytological studies on some South Indian grasses. Proc. 2nd Acad. agric. Sci. Agri. Coll. and Res. Instt., Coimbatore. 63-74.

Darlington, C. D. and Wylie, A.P. 1955. Chromosome Atlas of Flowering Plants. George Allen and Unwin Ltd., London.

Donald, G. DeLisle, 1963. Taxonomy and distribution of the genus Cenchrus. Iowa State J. Sci. 37: 259-351.

Fisher, W. D., Bashaw, E. C. and Holte, E. C. 1954 . Evidence for apomixis in Pennisetum ciliare and Cenchrus setigerus. Agron. J. 46: 401-404.

Jagannath, D. R. 1963. Microsporogenesis in relation to fertility in three species of Cenchrus. M. Sc., (Ag.) Dissen. Madras Univ. (Unpubl.). Abstract in Madras agric. J. 51: 362: 1964.

Jogindernath and Swaminathan, M. S. 1957. Chromosome numbers of some grasses. Indian J. Genet. 17: 102.

Patil, B. D., (Miss) Vohra, S. K. and Joshi, A. B. 1961. Chromosome numbers in some forage grasses. Curr. Sci. 30: 393.

Ponnaiya, B. W. X., Raman, V.S. and Jagannath, D. R. 1966. Two new chromosomal races in the Cenchrus complex. Sci. and Cult. 32: 195-196.

Ramaswamy, K. R. and Raman, V.S. 1969. An intervarietal hexaploid hybrid in Cenchrus ciliaris. Madras agric. J. 56: 272-277.

- and - 1970. Polyhaploidy in Cenchrus setigerus. Madras agric. J. 57: 164-168.

-, - and Madhava Menon, P. 1969. An analysis of morphological variation in relation to chromosomal forms in the Cenchrus complex. J. Indian bot. Soc. 48: 102-111.

Synder, L. A., Herandez, A. R. and Warmke, H. E. 1955. The mechanism of apomixis in Pennisetum ciliare. Bot. Gaz. 116: 209-221. 